\title{
Decomposition of Different Litter Fractions in Agroforestry System of Central India
}

\author{
Garima Gupta ${ }^{*}$, R.S. Yadav ${ }^{2}$ and Deepak Maurya ${ }^{3}$ \\ ${ }^{1}$ Maya College of Agricculture and Technology, Dehradun-248011, India \\ ${ }^{2}$ ICAR- Indian Institute of Soil and Water Conservation, Regional Centre, Datia-475 661, India \\ ${ }^{3}$ ICAR-NBSSLUP, Regional Centre, Kolkata-700091, India \\ *Corresponding author
}

\section{A B S T R A C T}

Keywords

Agroforestry,

Decomposition,

Nutrient cycling,

Substrate quality.

Article Info

Accepted:

17 July 2017

Available Online:

10 September 2017
Albiziaprocera is the native and most common agri silvicultural /agrosilvopastutal tree species of Semi-arid regions of Central India. This study focused on litter decomposition and subsequent nutrient release $(\mathrm{N}, \mathrm{P}, \mathrm{K})$ from litter fall under six-year old A. procera in agroforestry system. The average weight loss from different fractions of litter of A. procera, pod litter shows maximum decay followed by leaves and petiole Pod litter got the maximum decay rate coefficient indicate faster rate of its decomposition. For 95 percent decay leaf, petiole and pod litter decomposed faster under A. procera + crop. Decomposition of A. procera litter is positively correlated with $\mathrm{N}, \mathrm{P}$ and hemicellulose concentration of litter and negatively correlated with lignin, $\mathrm{C} / \mathrm{N}$ ratio, and lignin/ $\mathrm{N}$ ratio. Nutrient release from litter of A. procera followed the trend: $\mathrm{K}>\mathrm{N}>\mathrm{P}$ and was found higher from pod followed by leaves and petiole. The added nutrients may contribute to the sustainability of soil fertility, which is becoming an important phenomenon for agroforestry practices.

\section{Introduction}

Agroforestry is an ideal scientific approach for eco-restoration of degraded lands and sustainable resource management (Tripathi et al., 2009), in which litter fall is one of the main natural physiological phenomenon in trees having enormous implications in nutrient recycling, soil biodiversity, soil reclamation, allelopathy and yield of understory crops in agroforestry. It is a fundamental process in nutrient cycling and it is the main means of transfer of organic matter and mineral elements from the vegetation to the soil surface (Regina et al., 1999). Litter accumulation on the topsoil depends on several factors i.e. plant species, climate, land use types, decomposers population and their activities (Fernandes et al., 1997) and their decomposition process is influenced by a number of factors such as microclimate, mainly temperature and humidity, litter quality, soil nutrient content and the qualitative and quantitative compositions of decomposer communities (Anderson and Swift 1983, Dawoe et al., 2010). The choice of the tree species for agroforestry is influenced by knowledge of the species performance and their economic and environmental benefits. It is understood 
that quality or the initial chemical characteristics of litter played great role in the process of decomposition (Swift et al., 1979). Nevertheless, the decomposition of litter in agroforestry system differs from that of in the natural forest and in the agricultural system, because of differences in the types and quality of organic inputs (Mafongoya et al., 1998). A balance between litter deposition and decomposition regulates the accumulation of organic matter within an ecosystem (Singh et al., 2004). Over all, the product of litterfall decomposition is facilitating the formation of soil organic matter and return nutrient into soil (Odiwe and Muoghalu, 2003; XulucTolosa et al., 2003). Magnitude of soil enrichment depends upon the amount of litter fall and quality of the litter added. Both higher amount and quality of litter added in the system adds more nutrients and vice versa (Yadav et al., 2008). This paper discusses litter dynamics to with reference to decomposition and nutrient cycling patterns in agroforestry systems in Bundelkhand, central India.

\section{Materials and Methods}

\section{Study site and plant material}

The study was conducted in six year old $A$. procera based agroforestry system at research farm of National Research Centre for Agroforestry, Jhansi, Uttar Pradesh, India. The experimental field is situated at $25^{\circ} 27^{\prime}$ North latitude and $78^{\circ} 35^{\prime}$ East longitudes, $271 \mathrm{~m}$ asl in the semi-arid region of the Central Indian Plateau. Average annual rainfall of the region is $806 \mathrm{~mm}$, about $80 \%$ of which occurs between June to September with intermittent dry spells. The mean monthly temperature is generally high, with high degree of variation between a maximum $39.8^{\circ} \mathrm{C}$ in May and June and minimum temperature of $5.8^{\circ} \mathrm{C}$ in December and January. In summer, temperature occasionally reached up to $48^{\circ} \mathrm{C}$. The mean monthly evaporation in the region is highest in AprilJune (9.40-15.2mm) and it ranges from 1.90$6.00 \mathrm{~mm}$ during other months of the year. During 2006, total rainfall received was $375.20 \mathrm{~mm}$ spread over 30 rainy days. During 2007 total rainfall received was $554.8 \mathrm{~mm}$ spread over 40 rainy days. The soil in the experimental field is Parwa representing intermixed black and red soil group of Bundelkhand region (U.P.), India, falling under the soil order Alfisol. It is medium in texture, moisture retentive and workability, prone to crust whenever drought spell exceeds 2-3 weeks even under mild evaporation situation.

The experiment field was established as agri silviculture (crop + tree) system with Albizia procera as the tree fractions. A. procera was planted in at spacing of $8 \mathrm{~m} \mathrm{x} 4 \mathrm{~m}$ in plot size of $576 \mathrm{~m}^{-2}$ (18 trees plot-1) with three replications. In the established experiment, following pruning regimes were maintained for the studies on decomposition of litter fall: Under A. procera blackgram - mustard crop sequence were taken as intercrop. In Kharif season (Black gram) the trails were fertilized with $20 \mathrm{~kg} / \mathrm{ha} \mathrm{N}, 40 \mathrm{Kg} / \mathrm{ha} \mathrm{P}$ and in rabi season (mustered) $60 \mathrm{Kg} / \mathrm{ha} \mathrm{N}, 40 \mathrm{Kg} / \mathrm{ha} \mathrm{P}$ and $40 \mathrm{Kg} / \mathrm{ha} \mathrm{K}$ were applied. Inter crop black gram is rainfed in both pruning regime, therefore mustard is irrigated twice a year (1st at flowering and 2nd at siliquae formation).

\section{Litter bag incubation, decomposition and nutrient analysis}

Freshly fallen/ sense cent litter (leaves, petiole and pods) of Albizia procera were collected from field during March/ April 2006 and oven dried at $72^{\circ} \mathrm{C}$ till constant weight. The standard litterbag technique (Anderson \& Ingram, 1989) was employed for characterizing litter decomposition dynamics. Samples of $5.0 \mathrm{~g}$ of each fractions of the tree 
were transferred to nylon mesh bags (20x20 $\mathrm{cm}, 2 \mathrm{~mm}$ mesh size). The bags [432( $2 \times 3 \times 3 \times 24)]$ were randomly kept on the soil surface below respective pruning wise tree canopies on $1^{\text {st }}$ June 2006 in experimental field. Each month, 3 litter bags for each litter fractions of A. procera were collected from the floor of the different land sues. The litter samples thus drawn were washed under a fine jet of water using a fine mesh screen to remove all the adhered soil particles, dried at $72^{\circ} \mathrm{C}$ to constant weight, weighed and ground in a Wiley Mill to pass through a $1 \mathrm{~mm}$ mesh screen. Samples were analyzed for N, P and K analysis. Soil samples were also drawn beneath litterbags quarterly to evaluate extent of enrichment in soil fertility subsequent to decomposition of the litter.

\section{Data analysis}

To evaluate nutrient release pattern, nutrient remaining in the decomposing litter were estimated by equation (Bockhelm et al., 1991)

$\%$ Nutrient remaining $=\left(\mathrm{C} / \mathrm{C}_{0}\right) \times\left(\mathrm{DM} / \mathrm{DM}_{0}\right)$ $\mathrm{x} 10^{2}$

Where,

$\mathrm{C}=$ Concentration of nutrient element in decomposition litter at the time of sampling

$\mathrm{C}_{0}=$ Concentration of nutrient element at the beginning of the study

$\mathrm{DM}=$ Mass of dry matter at the time of sampling

$\mathrm{DM}_{0}=$ Initial dry matter of the biomass kept for decomposition

The decay rate coefficient $(k)$ of the decomposing litter of different fractions for the entire study period was calculated through the negative exponential decay model of Olson (1963) as represented by the equation: $\mathrm{X} / \mathrm{X}_{0}=\mathrm{e}^{-\mathrm{kt}}$
Further, following Olson (1963), the time required for 50 (half-life) \% weight losses was estimated from $\mathrm{k}$ values using the equation:

$\mathrm{t}_{50}=\operatorname{In}(0.5) /-\mathrm{k}=-0.693 /-\mathrm{k}$

Similarly, time taken for $95 \%$ decay can be estimated as follows

$\mathrm{t}_{0.95}=2.9957 / \mathrm{k}$

The effect of land use of Albizia procera on decomposition, nutrient dynamics and cumulative impact on soil properties was tested by means of ANOVA using the General Linear Model of SYSTAT Ver.9 (SYSTAT Inc. 1998).

\section{Results and Discussion}

\section{Decomposition and decomposition coefficient $(\mathbf{k})$}

Decomposition of A. procera litter is positively correlated with $\mathrm{N}, \mathrm{P}$ and hemicellulose concentration of litter and negatively correlated with lignin, $\mathrm{C} / \mathrm{N}$ ratio, and lignin/ $\mathrm{N}$ ratio (Table 1). The average weight loss from different fractions of litter (Fig. 1) of A. procera was higher in first four months due to the peak season of rainfall (from June to September). Pod litter got the maximum decay rate coefficient indicate faster rate of its decomposition (Table 2). For 95 percent decay leaf litter and fruit litter decomposed faster under A procera + crop, while petiole litter was decomposed faster under cropping.

\section{Nutrient release}

The nutrient release pattern of $\mathrm{N}, \mathrm{P}$ and $\mathrm{K}$ are represented for each litter fractions in figure 2. $\mathrm{N}$ release data evident that $A$. procera pod litter released $\mathrm{N}$ at faster rate followed by leaf and petiole. Across fractions of decomposing 
litter, A. procera litter under A. procera + crop released maximum $\mathrm{N}$. $\mathrm{P}$ release was found more than $95 \%$ in decomposing leaf litter under both land use. $\mathrm{K}$ release data evident that mineralization of $\mathrm{K}$ was maximum from $A$. procera pod litter followed by leaf and petiole. Across fractions of decomposing litter, under A. procera + crop released maximum $\mathrm{K}$, except for petiole litter under which cropping released maximum $\mathrm{K}$. Nutrient release from litter of $A$. procera followed the trend: $\mathrm{K}>\mathrm{N}>\mathrm{P}$ and was found higher from pod followed by leaves and petiole.

Fig.1 Per cent weight loss of different litter fractions of A. procera under different land use
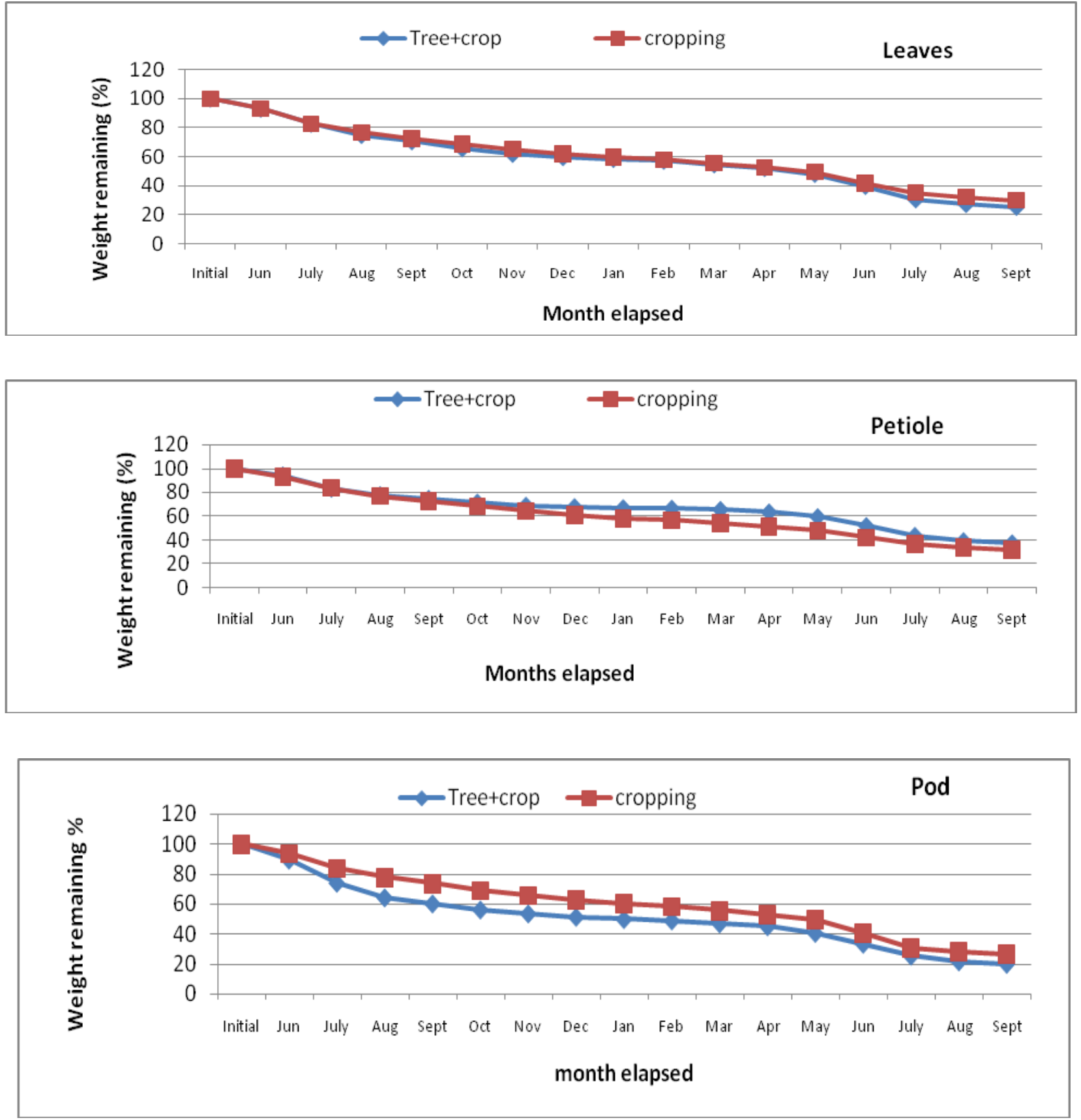
Fig.2 Nutrient release from decomposing litter fractions of $A$. procera under different land use
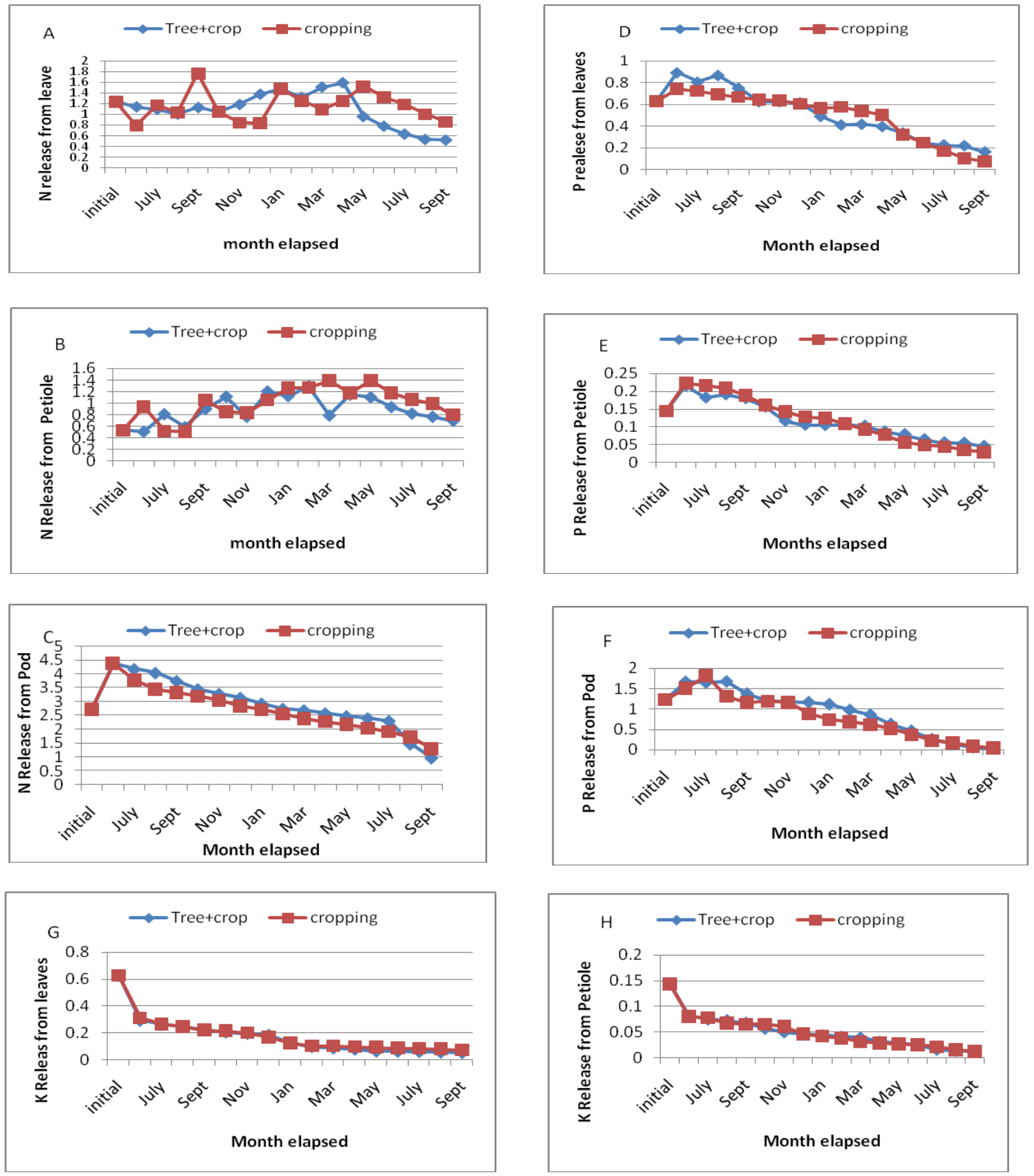


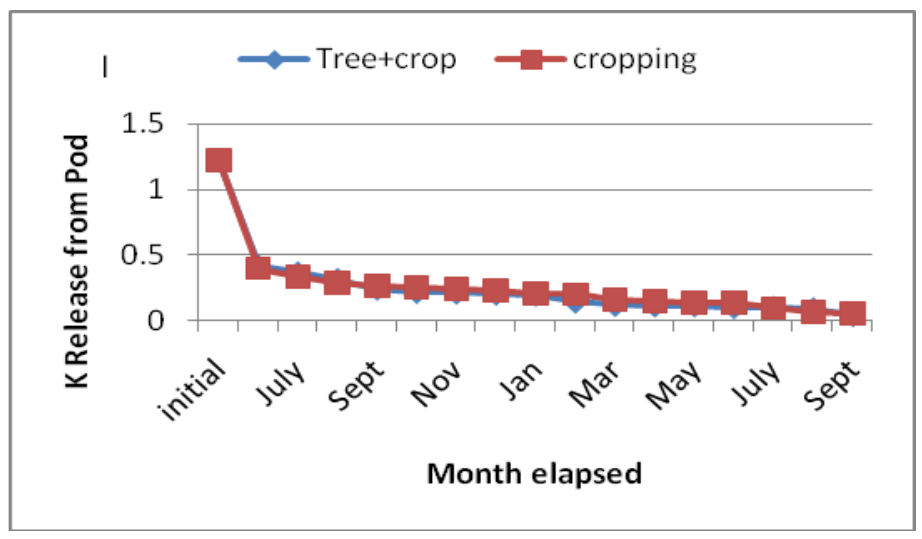

Table.1 Pearson correlation coefficient between $A$. procera litter substrate quality and decomposition constant averaged across the different land use

\begin{tabular}{lccc}
\hline Quality parameters & Leaves k & Petiole k & Pods k \\
\hline $\mathrm{C}$ & 0.029 & -0.154 & 0.141 \\
$\mathrm{~N}$ & $0.483^{* *}$ & $0.404^{*}$ & $0.383^{*}$ \\
$\mathrm{P}$ & 0.041 & $0.425^{*}$ & $0.371^{*}$ \\
Lignin & -0.192 & -0.334 & -0.399 \\
C/N & -0.052 & $-0.369^{*}$ & -0.367 \\
Lignin/N & $-0.494^{* *}$ & -0.327 & -0.154 \\
ADF & -0.346 & -0.113 & $-0.386^{*}$ \\
Cellulose & $-0.398^{*}$ & 0.0120 & -0.151 \\
Hemi cellulose & $0.484^{* *}$ & 0.125 & 0.292 \\
L/LC & 0.127 & -0.246 & -0.241 \\
C/P & -0.031 & $-0.430^{*}$ & -0.325 \\
\hline
\end{tabular}

* Significant at $\mathrm{P}<0.05, * * \mathrm{P}<0.01$

Table.2 Decomposition parameters of different fractions of litter biomass of A. procera

\begin{tabular}{|c|c|c|}
\hline \multirow{2}{*}{$\begin{array}{l}\text { Decay } \\
\text { parameters }\end{array}$} & \multicolumn{2}{|c|}{ Land uses } \\
\hline & A. procera + crop & Cropping \\
\hline \multicolumn{3}{|c|}{ Leaves } \\
\hline Decay constant & 0.0028 & 0.0026 \\
\hline $\mathrm{t}_{50}$ (days) & 247 & 273 \\
\hline $\mathrm{t}_{95}$ (days) & 1068 & 1180 \\
\hline $\mathrm{t}_{99}$ (days) & 1780 & 1967 \\
\hline \multicolumn{3}{|c|}{ Petiole } \\
\hline Decay constant & 0.0020 & 0.0024 \\
\hline $\mathrm{t}_{50}$ (days) & 344 & 292 \\
\hline $\mathrm{t}_{95}$ (days) & 1490 & 1265 \\
\hline $\mathrm{t}_{99}$ (days) & 2483 & 2108 \\
\hline \multicolumn{3}{|c|}{ Pod } \\
\hline $\begin{array}{l}\text { Decay } \\
\text { constant }\end{array}$ & 0.0034 & 0.0028 \\
\hline $\mathrm{t}_{50}$ (days) & 206 & 251 \\
\hline $\mathrm{t}_{95}$ (days) & 893 & 1085 \\
\hline$t_{99}$ (days) & 1489 & 1809 \\
\hline
\end{tabular}




\section{Initial substrate quality}

Substrate (litter/biomass) quality, quantity and quality of decomposer organisms are the primary determinants of any biomass decay rates (Swift et al., 1979). In this study, the differences in rates of decomposition of different fractions of litter and biomass of $A$. procera under different land uses and pruning regimes could be related to differences in substrate (litter) quality and variations in microenvironment beneath $A$. procera in cropping. The higher concentration of $\mathrm{N}$ and lower $\mathrm{C} / \mathrm{N}$ ratio in the biomass of $A$. procera was probably responsible for its faster decomposition and lower concentration of $\mathrm{N}$ in the petiole of $A$. procera brought slower rate of decomposition. A positive effect of $\mathrm{N}$ concentration on decomposition was also reported by several workers (Melillo et al., 1982; Pandey and Singh, 1982; Sandhu et al., 1990; Shukla et al., 1990, Das and Chaturvedi, 2003 and Yadav et al., 2008).

\section{Litter decomposition}

During biomass and litter decomposition, nutrients may endure three sequential stages (i) initial release stage in which leaching predominate (ii) the net immobilization stage in which nutrients are imported in the residual litter mass, and (iii) the net release stage in which an absolute decrease in the nutrient concentration occurs in the residual litter mass (Staff and Berg, 1982). In the present study, increase in $\mathrm{N}$ and $\mathrm{P}$ concentration of decomposing different fractions of litter of $A$. procera under different land uses and pruning regimes could be ascribed to microbial immobilization (Joergensen and Meyer, 1990 and Das and Chaturvedi, 2003) and the second phase of decrease to the mineralization of the nutrients from the decomposing litter. Tripathi et al., (2009) reported that litter decomposition was fast during rainy season and slow during winter season.

\section{Total nutrient release from decaying litter}

Nutrient release from litter fractions of followed the trend: $\mathrm{K}>\mathrm{N}>\mathrm{P}$ and found higher in pod followed by leaves and petiole. Comparatively higher initial concentration of $\mathrm{N}, \mathrm{P}, \mathrm{K}$ in the pod litter A. procera followed by leaves litter indicated that capabilities of the pod and leaf litter to re-translocated these nutrients were lower during the senescence litter (Hossain et al., 2011, Berg and laskowski 2006). The faster decreasing $\mathrm{K}$ concentration from all fractions of litter was observed as it is a non-structural element and highly mobile to be the most leachable action during the decomposition of litter (Marschner 1995, Guo and Sims 2002 and Tisdale et al., 1993). N structurally bound with cell wall and leaf contained comparatively lower concentration of P (Hossain et al., 2011, Defelice 1993 and Mayer et al., 1973). During decomposition, increase concentration of nutrients $(\mathrm{N}, \mathrm{P}, \mathrm{K})$ at different stages of decomposition was attributed to microbial or non-microbial immobilization in the residual litter while litter act as a surface for fungi or heterotrophic organism. (Hossain et al., 2011, Lin et al., 2007 and Mahmood et al., 2014)

\section{References}

Anderson, J.M., and Ingram, J.S.I. 1989. Tropical Soil Biology and Fertility: A Handbook of Methods. CAB International, Wallingford, U.K., Pp. 171.

Anderson, J.M., and Swift, M.J. 1983. Decomposition in tropical forest. Pages 287-309, In: Sutton, S.L.; Whitmore, T.C. and Chadwick, A.C. (Editors) Tropical Rain Forest: Ecology and Management. Blackwells, Oxford 
Berg, B., and Laskowski R. 2006. Litter Decomposition: A Guide to Carbon and Nutrient Turnover, Elsevier Scientific Publishing, Amsterdam, the Netherlands.

Bockhelm, J.G., Jepsen, E.A. and Heisey, D.M. 1991. Nutrient dynamics in decomposing leaf litter of four tree species on a sandy soil in North Western Wisconsin. Can. J. For. Res., 21: 803-812.

Das, D.K., and Chaturvedi, O.P. 2003. Litter quality effects and decomposition rates of forestry plantations. Trop. Ecol., 44: 259-262.

Dawoe, E.K., Isaac, M.E. and Quashie-Sam, J. 2010.Litterfall and litter nutrient dynamics under cocoa ecosystems in lowland humid Ghana. Plant Soil, 330: 55-64.

DeFelice, K., 1993. Nitrogen in the Plant, University of Missouri Extension Press.

Fernandes, E.C.M., Biot, Y.; Castilla, C.; Canto, A. and Matos, J.C.S. 1997. The impact of selective logging and forest conversion for subsistence agriculture and pastures on terrestrial nutrient dynamics in the Amazon. Ciecia Cultura 49: 34-47

Guo, L., and Sims R. E. H., 2002. Eucalypt litter decomposition and nutrient release under a short rotation forest regime and effluent irrigation treatments in New Zealand: II. Internal effects. Soil Biology \& Biochemistry, vol. 34, no. 7, pp. 913-922.

Hossain, M., Siddique M. R. H., Rahman M. S., Hossain M. Z., and Hasan M. M. 2011. Nutrient dynamics associated with leaf litter decomposition of three agroforestry tree species (Azadirachta indica, Dalbergia sissoo, and Melia azedarach) of Bangladesh. Journal of Forestry Research, 22 (4): 577-582.

Joergensen, R.G., and Meyer, B. 1990. Nutrient changes in decomposing leaf litter assessed using a solution flux approach. J. Soil Sci., 41:279-293

Lin, Y.M., Liu J. W., Xiang P., Lin P., Ding Z. H., and Sternberg L. Da Silveira Lobo, 2007. Tannins and nitrogen dynamics in mangrove leaves at different age and decay stages (Jiulong River Estuary, China). Hydrobiologia, vol. 583(1): 285-295.

Mafongoya, P.L., Giller, K.E. and Palm, C.A. 1998. Decomposition and nitrogen release patterned of tree pruning and litter. Agroforestry System 38: 77-79.

Mahmood, H., Siddique M. R. H., Abdullah S. M. R., Saha S., Ghosh D.C. Rahman Md. Saidur and Limon Sharif Hasan. 2014. Nutrient dynamics associated with leaching and microbial decomposition of four abundant mangrove species leaf litter of the Sundarbans, Bangladesh. Wetlands, 34, (3): 439-448.

Marschner, H., 1995. Mineral Nutrition of Higher Plants, Academic Press, New York, NY, USA.

Melillo, J.M., Aber, J.D. and Musatore, J.F. 1982. Nitrogen and lignin control of hardwood leaf litter decomposition dynamics. Ecol., 63: 621-626.

Meyer, B. S., Anderson D. B., Bohning R. H. and Fratiane D. G. 1973. Introduction to Plant Physiology, D. Van Nostrand, New York, NY, USA.

Odiwe, A.I., and Muoghalu, J.I. 2003. Litterfall dynamics and forest floor litter as influenced by fire in a secondary lowland rain forest in Nigeria. Tropical Ecology. 44(2): 243-251.

Olson, J.S., 1963. Energy storage and balance of production and decomposers in ecological systems. Ecol., 44: 322-331.

Pandey, U., and Singh, J.S. 1982. Leaf litter decomposition in an Oak conifer forest in Himalaya.The effect of climate and chemical composition. For., 55: 47-59. 
Regina, M., Wetrington, B. D. and Vanastru FF aldi-De Vuono 1999.Litter and nutrient content in two Brazilian tropical Forest. Revtabrasil. Bot. 22: 1999.

Sandhu, J., Sinha, M. and Ambasht, R.S. 1990. Nitrogen release from decomposing litters of Leucaena leucophloea in the dry tropics. Soil Biol. Biochem., 22: 859-863.

Shukla, A.K., Tiwari, B.K. and Mishra, R.R. 1990. Decomposition of potato litter in relation to microbial population and plant nutrients under field condition. Pedobiol, 34: 287-298.

Singh, R.K., Dutta, R.K. and Agarwal, M. 2004 Litter decomposition and nutrient release in relation to atmospheric deposition of Sand $\mathrm{N}$ in a dry tropical region. Pedobiologia 48: 305-311

Staff, H., and Berg, B. 1982. Release and accumulation of plant nutrients in needle litter during decomposition. Long term decomposition of Scot pine needle litter. II. Can. J. Botany, 60: 1561-1568.

Swift, M.J., Heal, O.W. and Anderson, J.M. 1979. Decomposition in terrestrial ecosystems. Blackwell Scientific, Oxford, Pp.372. Terrestrial Ecosystems. Blackwell s, Oxford. 372 Page.

Tisdale S. L., Nelson W. L., Beaton J. D., and Havlin J. L., 1993. Soil Fertility and Fertilizers, Prentice Hall, New Delhi, India, 5th edition.

Tripathi, O.P., Pandey, H.N. and Tripathi, R.S. 2009. Litter production, decomposition and physico-chemical properties of soil in 3 developed agroforestry systems of Meghalaya, Northeast India. African Journal of Plant Science 3(8): 160-167.

Xuluc-Tolosa, F.J., Vester, H.F.M.; RamirezMarcial, N.; Castellanos-Albares and Lawrence, D. 2003. Leaf litter decomposition of tree species in three successional phases of tropical dry secondary forest in Campeche, Mexico. Forest Ecology and Management. 174: 401-412.

Yadav, R.S., Yadav, B.L. and Chhipa, B.R. 2008. Litter dynamics and soil properties under different tree species in a semi-arid region of Rajasthan, India. Agrofor. Sys, 73: 1-12

\section{How to cite this article:}

Garima Gupta, R.S. Yadav and Deepak Maurya. 2017. Decomposition of Different Litter Fractions in Agroforestry System of Central India. Int.J.Curr.Microbiol.App.Sci. 6(9): 10891097. doi: https://doi.org/10.20546/ijcmas.2017.609.130 